Int. J. Morphol.,

30(3):847-857, 2012.

\title{
An Anatomical Study of the Arterial Supply to the Soft Palate
}

\author{
Estudio Anatómico de la Irrigación Arterial del Paladar Blando
}

T. Maistry; L. Lazarus; P. Partab \& K. S. Satyapal

\begin{abstract}
MAISTRY, T.; LAZARUS, L.; PARTAB, P. \& SATYAPAL, K. S. An anatomical study of the arterial supply to the soft palate. Int. J. Morphol., 30(3):847-857, 2012.

SUMMARY: This study provides a detailed description of the arteries supplying the soft palate via: (i) ascending palatine; (ii) tonsillar; (iii) ascending pharyngeal; and (iv) lesser palatine arteries. Detailed dissections were performed on each side of thirty fetal and twenty adult head and neck specimens $(\mathrm{n}=100)$. This investigation documents the arteries terminating at the respective parts (superior, middle and inferior) of the soft palate and demonstrated that the majority of arteries terminated at the superior (83\%) and middle (63\%) parts, whereas the inferior part (34\%) was documented to receive the poorest arterial supply. The present study recognized anastomotic connections in $6 \%$ of fetal specimens i.e. (i) between the ascending palatine and lesser palatine arteries which terminated at the superior part of the soft palate in $4 \%$ of fetal cases, and (ii) between the ascending pharyngeal and recurrent pharyngeal arteries which terminated at the inferior part in $2 \%$ of fetal specimens. The position and relations of the soft palate arteries is of significance to minimize the risk of vascular disruption and myomucosal or mucosal flap failure during cleft palate repair and for the surgical correction of velopharyngeal insufficiency.
\end{abstract}

KEY WORDS: Soft palate; Arterial supply; Territory; Anastomosis.

\section{INTRODUCTION}

The arterial blood supply to the soft palate is traditionally described as being from the ascending palatine (branch of the facial artery), greater palatine (branch from the third part of the maxillary artery), and ascending pharyngeal (branch of the external carotid artery) arteries (Moore et al., 2009; Standring, 2009). Variations to this description include additional contributions from the recurrent pharyngeal (branch of the external carotid artery) and lesser palatine (branch of the third part of maxillary artery) arteries (Huang et al., 1998a) and tonsillar branches of the facial artery (Cheng et al., 2000). Anastomoses between the greater palatine and ascending palatine arteries (Mercer \& MacCarthy, 1995a, 1995b), ascending palatine and recurrent pharyngeal arteries, lesser, greater and ascending palatine arteries (Huang et al., 1998b), and mucosal branches of the lesser palatine, ascending pharyngeal and tonsillar arteries (Cheng et al.) were documented. Broomhead (1951) conducted an investigation on a single fetal specimen and provided a limited description of the soft palate arteries. Girgis (1966) examined the arterial supply only to the musculus uvula whilst Freelander (1992) described the supply to the levator and tensor veli palatini muscles. Standard anatomical textbooks misrepresent the arterial supplies to the soft palate (viz. greater palatine, ascending palatine and ascending pharyngeal arteries; or lesser palatine, greater palatine and ascending palatine arteries) which could be misleading to the surgeon during reconstructive surgery (Hollinshead, 1954; Standring). Mercer \& MacCarthy (1995b) described the arterial supply to the pharynx in detail and Huang et al. (1998b) examined the velopharyngeal muscles in detail. A review of the literature revealed a limited description of the arterial anatomy of the soft palate (Cheng et al.). Despite this lack of information, many surgical procedures have been documented for cleft palate repair and for the correction of velopharyngeal insufficiency (Rosenthal, 1924; Rosselli, 1935; Hynes, 1950; Skoog, 1965; Orticochea, 1968; Kriens, 1969; Furlow, 1986). During the latter procedures, the position and relations of the soft palate arteries is of significance to minimize the risk of vascular disruption and myomucosal or mucosal flap failure (Huang et al., 1998a).

The aim of this study was to clearly document the arterial branching patterns to the soft palate, the arterial anastomotic connections between the right and left sides of the soft palate and the variations and anomalous arterial branches of the soft palate. 


\section{MATERIAL AND METHOD}

Thirty fetal (gestational age: 17- 22 weeks) and twenty adult head and neck specimens were used in this study. A total of fifty head and neck specimens were utilized, $(n=100$ sides i.e. fetuses [60/100] - right [30/50]; left [30/50] and adults [40/100] - right [20/50]; left [20/50]. These specimens were obtained from the Department of Clinical Anatomy, University of KwaZulu Natal (UKZN) (Westville and Nelson R Mandela School of Medicine Campuses). Ethical clearance was obtained from the Bio-Medical Research Ethics Committee of UKZN (Ethical clearance number BF157/07). Cadavers displaying evidence of previous pharyngeal surgery and significant oropharyngeal pathology were excluded. From the sample, 3 adult specimens were injected with latex via the common carotid artery. The detailed dissection (using the technique of Agur \& Dalley, 2006) of the arteries supplying soft palate were completed under magnification with the aid of a Stemi DV 4 light microscope (Carl Zeiss Inc, Germany) and the results were recorded at the origin and termination for the respective soft palate arteries and photographed. Particular attention was paid to the 3 divisions of the soft palate (superior, middle and inferior parts) in order to determine the territory of supply to the soft palate (Table I, Fig. 1). Anastomotic connections (where relevant) and variations (where relevant) to the respective parts (superior, middle and inferior) of the soft palate were also investigated. For statistical comparisons, t-tests for the soft palate arteries at their origin and termination into the respective parts were used, with a $p$ $<0.05$ level indicating significance.

Table I. Divisions of soft palate.

\begin{tabular}{lr}
\hline Divisions & Description \\
\hline $\begin{array}{l}\text { Superior part } \\
\text { Middle part }\end{array}$ & $\begin{array}{r}\text { From posterior margin of hard palate to point of attachment of superior margin of levator veli palatini and point } \\
\text { of origin of margin border of palatoglossus. } \\
\text { the superior and inferior margins of the palatoglossus originates from the palatine aponeurosis of soft palate. }\end{array}$ \\
$\begin{array}{r}\text { Inferior part } \\
\text { From the point of attachment of the inferior margin of levator veli palatini and the origin of the inferior margin of } \\
\text { palatoglossus, extending distally. }\end{array}$
\end{tabular}

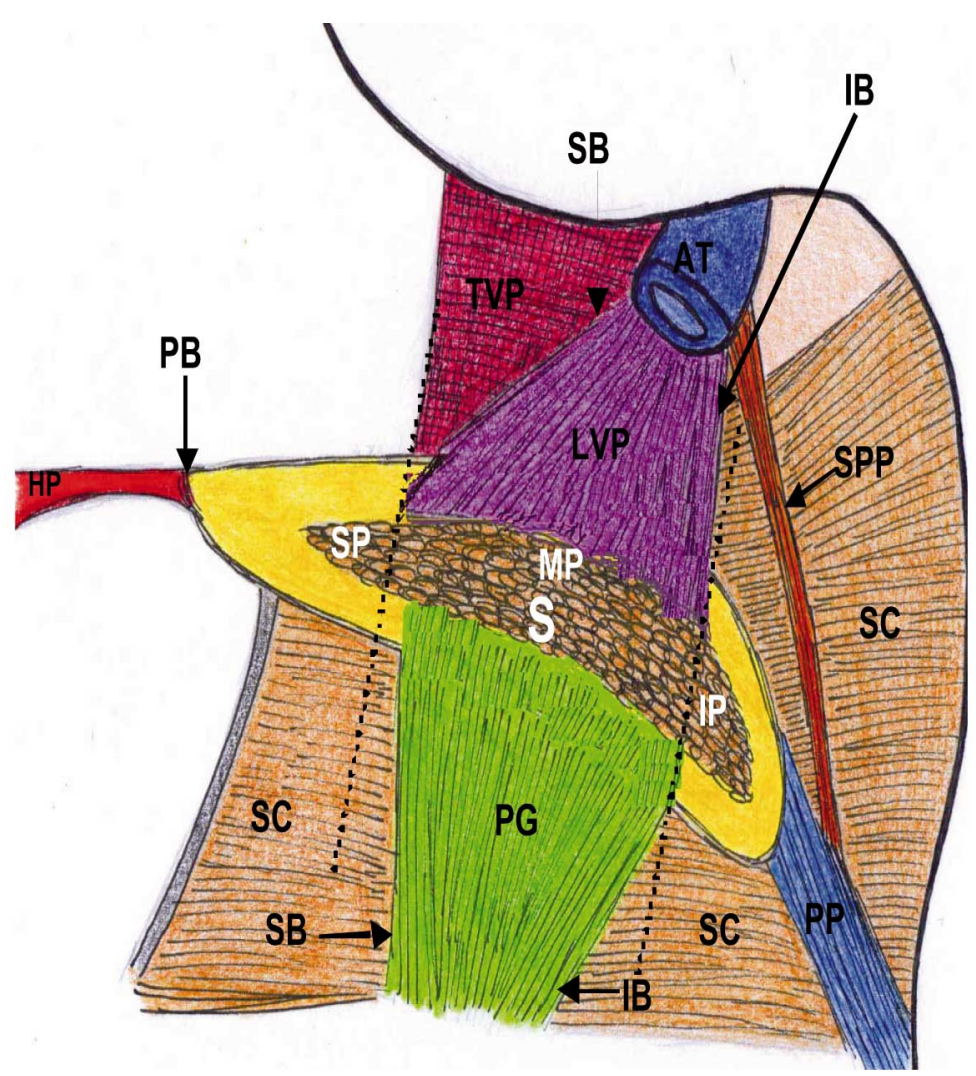

Fig. 1. Schematic representation of the divisions of the soft palate. *Astericks represents the divisions (superior, middle and inferior parts) of the soft palate related to the attachment of the levator veli palatini and origin of the palatoglossus muscles.

Key = LVP: Levator veli palatini; TVP: Tensor veli palatini; PG: Palatoglossus; SC: Superior constrictor; SPP: Salpingopharyngeus; PP: Palatopharyngeus; S: Soft palate; AT: Auditory tube; HP: Hard palate; PB: Posterior margin; SB: Superior margin; IB: Inferior margin; SP: Superior part; MP: Middle part; IP: Inferior part. 


\section{RESULTS}

The soft palate was supplied by the following arteries viz. (i) ascending palatine artery demonstrated in $99 \%$ of cases; (ii) tonsillar artery in 5\% of dissections; (iii) ascending pharyngeal artery observed in $25 \%$; and (iii) lesser palatine artery depicted in $47 \%$ of cases (Table II).

\section{Origin of arteries supplying soft palate.}

(a) Ascending Palatine Artery. The ascending palatine artery originated from several sources viz: (i) facial artery (dominant) in 63\% of dissections (Fig. 2); (ii) external carotid artery in $31 \%$ of cases; (iii) lingual artery in $4 \%$ of dissections; and (iv) occipital artery in $2 \%$ of cases.

Fig. 2. a) The ascending palatine artery originating from the facial artery in an adult specimen (left lateral view).

Fig. 2b) Schematic representation of the ascending palatine artery originating from the facial artery (left lateral view).

* Dotted circular area depicts the lateral branch of the ascending palatine artery which ascended superficial to superior constrictor muscle and descended at upper border of superior constrictor muscle to supply soft palate

Key = APA: Ascending palatine artery;

ECA: External carotid artery; FA: Facial artery; MP: Medial pterygoid muscle; SC: Superior constrictor muscle;

SMG: Submandibular gland; SCM: Sternocleidomastoid muscle.
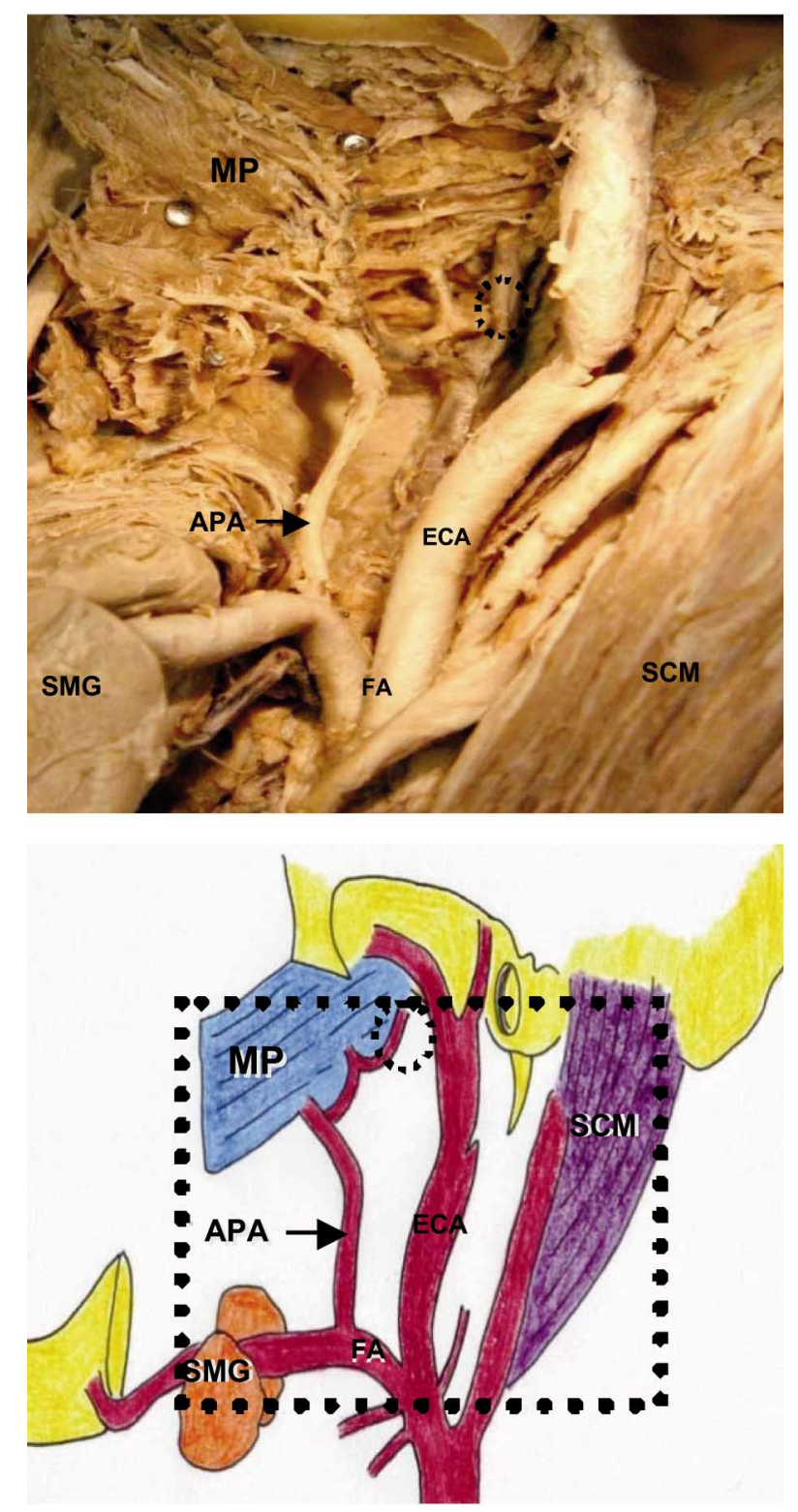

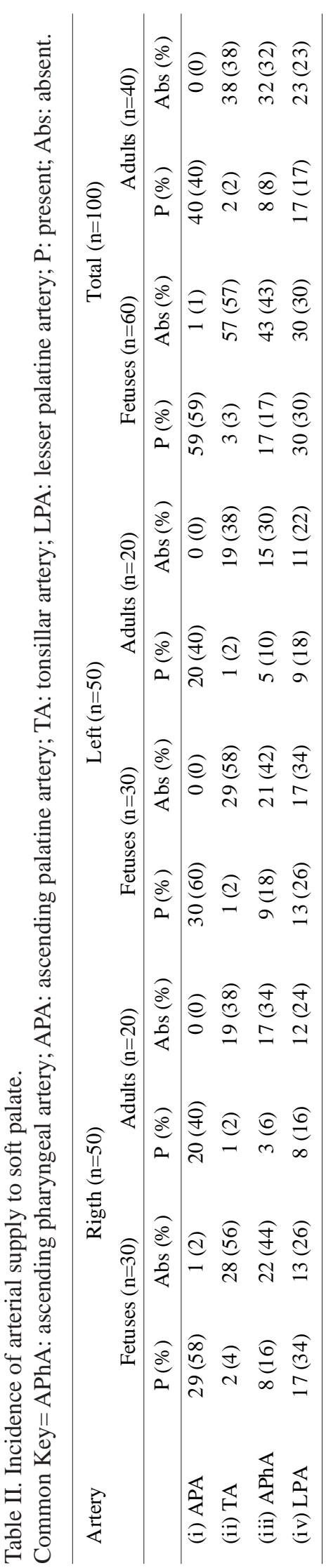

849 

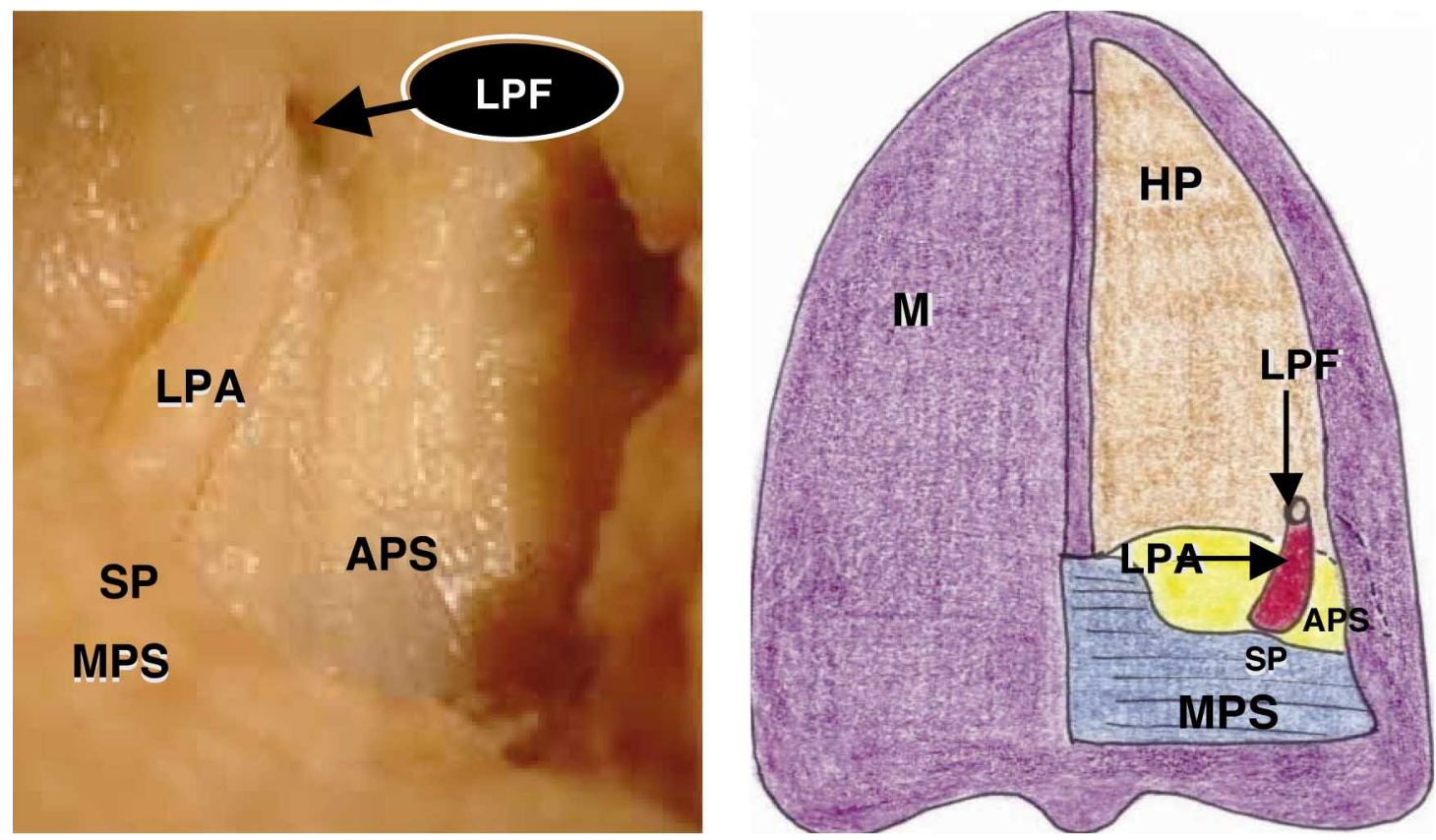

Fig. 3. a) The lesser palatine artery emerging from the lesser palatine foramen and terminating at the superior part of soft palate in a fetal specimen (inferior view). b) Schematic representation of the lesser palatine artery emerging from the lesser palatine foramen and terminating at the superior part of soft palate (inferior view).

Key = LPF: Lesser palatine foramen; LPA: Lesser palatine artery; APS: Aponeurotic part of soft palate; MPS: Muscular part of soft palate; SP: Superior part of soft palate; HP: Hard palate; M: Mucoperiosteum.

Figs. 4. a) and b) The superior part of the soft palate receiving a contribution from the ascending artery in an adult specimen (right medial view).

Fig. 4c) Schematic representation of the respective parts of the soft palate (superior and middle parts highlighted) (right medial view).
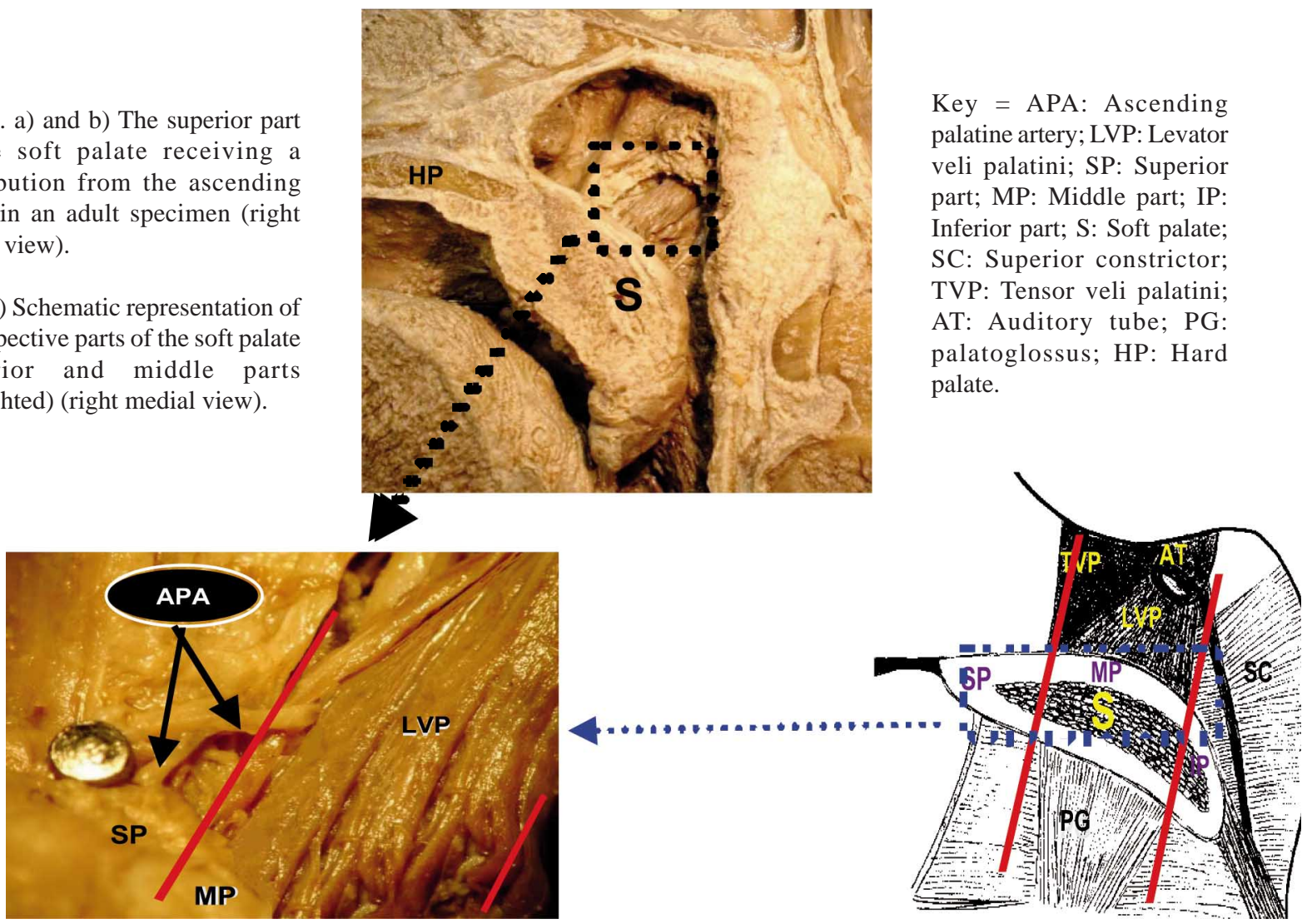

Key = APA: Ascending palatine artery; LVP: Levator veli palatini; SP: Superior part; MP: Middle part; IP: Inferior part; S: Soft palate; SC: Superior constrictor; TVP: Tensor veli palatini; AT: Auditory tube; PG: palatoglossus; HP: Hard palate. 


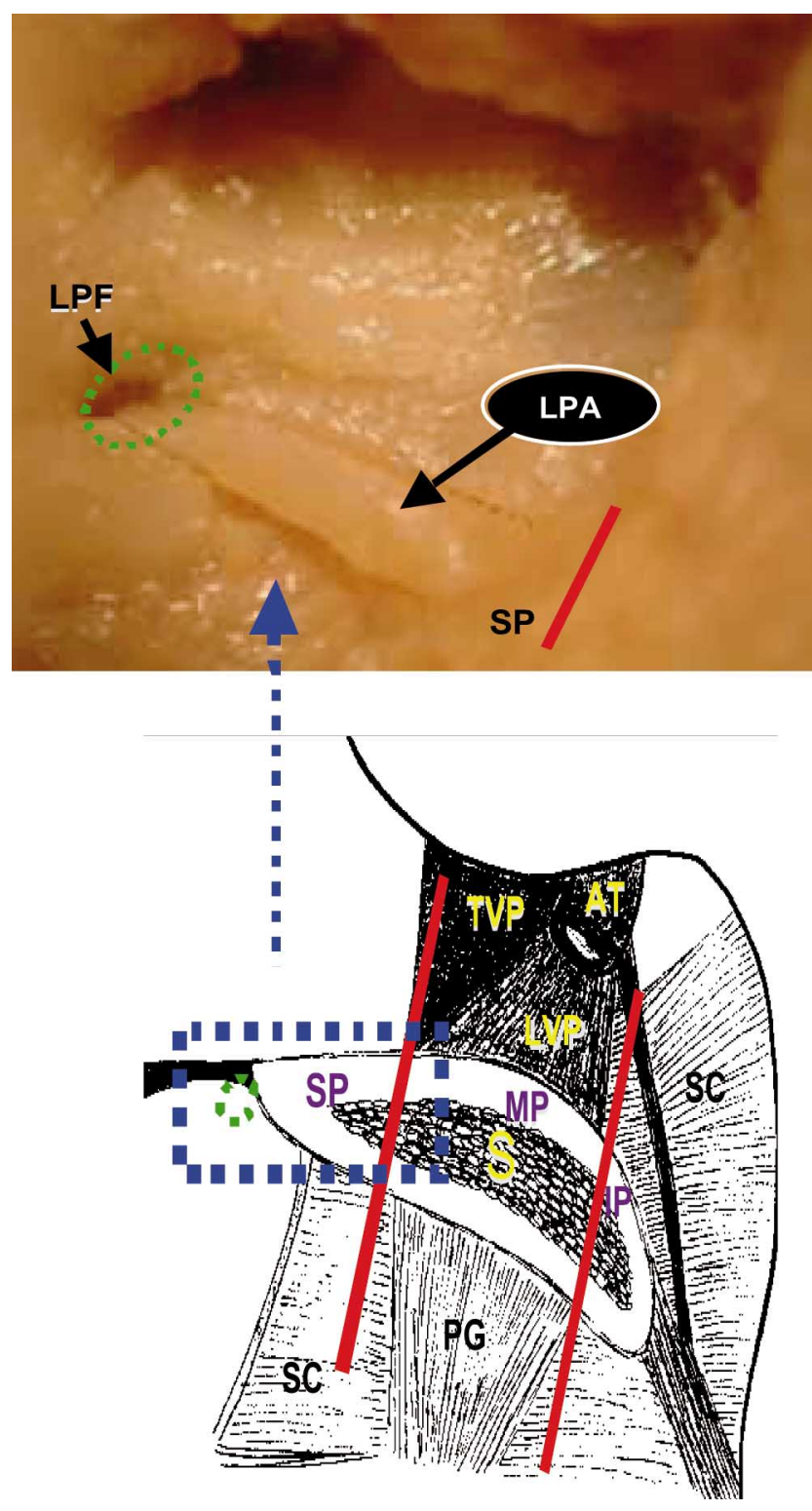

(b) Ascending Pharyngeal Artery. The ascending pharyngeal artery arose from the medial aspect of the external carotid artery in close relation to the bifurcation of the common carotid artery in $100 \%$ of specimens.

(c) Tonsillar Artery. The tonsillar artery was observed originating from the facial artery, in close range to the ascending palatine branch in $100 \%$ of dissections.

(d) Lesser Palatine Artery. The source vessels of the lesser palatine artery were not included in the dissection due to their course extending through bony structures. Nevertheless, the terminal vessels emerging from the lesser palatine foramen were traced to the soft palate and was demonstrated in $47 \%$ of cases (Fig. 3).
Fig. 5. a) The superior part of the soft palate receiving a contribution from the lesser palatine artery in a fetal specimen (right medial view). b) Schematic representation of the respective parts of the soft palate (superior part highlighted and depicts lesser palatine foramen) (right medial view).

Key $=$ LPA: Lesser palatine artery; LPF: Lesser palatine foramen; SP: Superior part; MP: Middle part; IP: Inferior part; S: Soft palate; PG: Palatoglossus; SC: Superior constrictor; TVP: Tensor veli palatini; LVP: Levator veli palatini; AT: Auditory tube.

\section{Territorial distribution}

Superior Part. A total incidence of $37 \%$ from the ascending palatine artery (Fig. 4) and $46 \%$ from the lesser palatine artery was observed terminating at the superior part of the soft palate (Table III) (Fig. 5).

Middle Part. Of the 100 specimens analyzed, 2\% from the ascending pharyngeal artery (Fig. 6) contributed to the middle part of the soft palate in fetal specimens. The middle part of the soft palate also demonstrated 61 branches (61\%) from the ascending palatine artery (Table IV) (Fig. 7).

Inferior Part. The inferior part of the soft palate received contributions from (i) ascending pharyngeal artery (21\%) (dominant); (ii) ascending palatine artery (8\%); and (iii) tonsillar artery (5\%) (Table V) (Fig. 8).

\section{Anastomotic connections}

(a) Anastomotic connection between ascending and lesser palatine arteries. The ascending palatine artery (laterally it originated from the facial artery, ascended superficial to the superior constrictor, descended medially over the superior border of the latter muscle, and emerged in close relation to the pterygoid hamulus) and the lesser palatine artery (emerged from the lesser palatine foramen) anatomosed and terminated at the superior part of the soft palate in $4 \%$ of foetal specimens (Fig. 9).

(b) Anastomotic connection between ascending and recurrent pharyngeal arteries. The ascending pharyngeal and recurrent pharyngeal arteries originated from the external carotid artery, ascended superficial to superior constrictor and emerged from the pharyngeal opening of auditory tube as single trunks, descended over the superior constrictor and terminated at the inferior part of the soft palate in $2 \%$ of fetal dissections. 


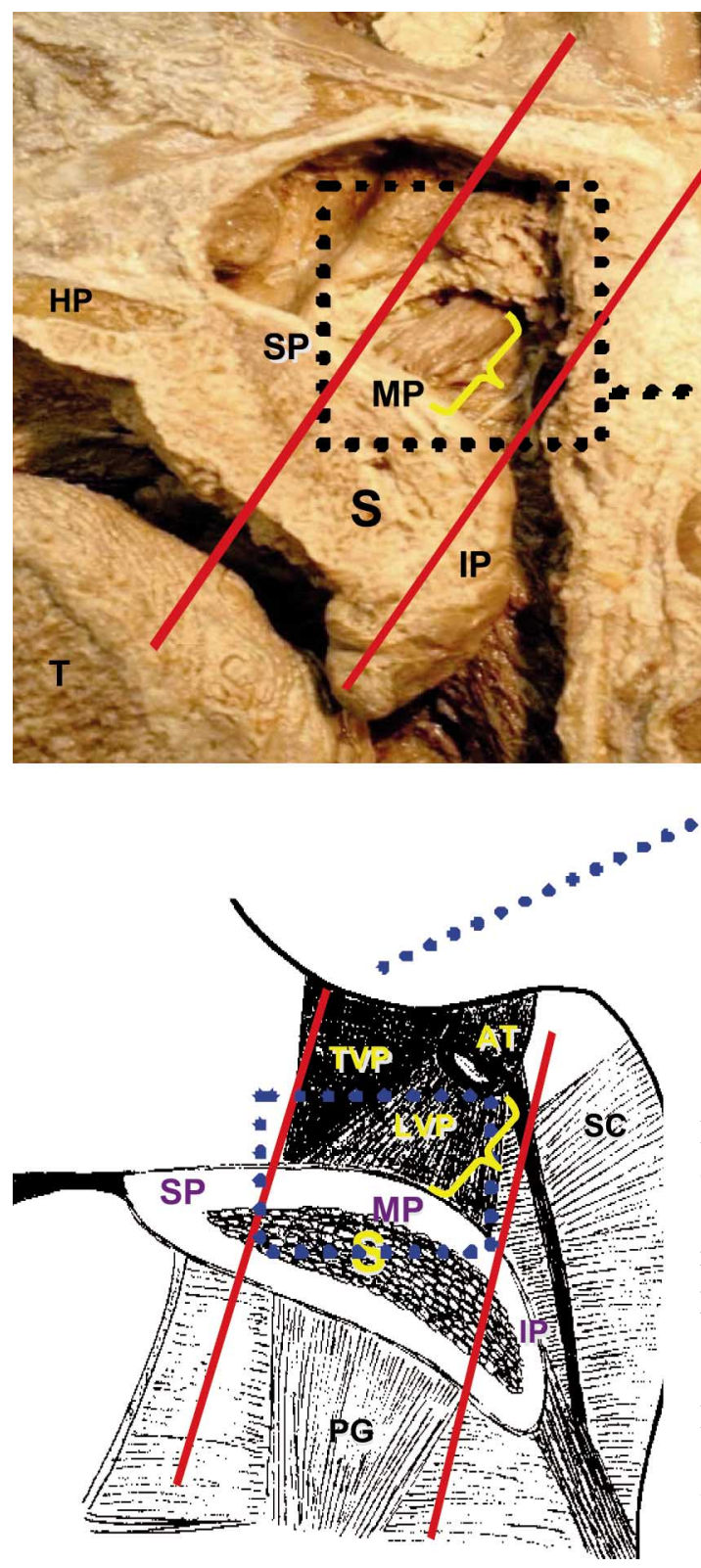

Fig. 6. a) and b) The middle part of the soft palate receiving a contribution from the ascending pharyngeal artery in an adult specimen (part of LVP removed) (right medial view). c) Schematic representation of the respective parts of the soft palate (middle part highlighted) (right medial view).

Key $=$ APhA: Ascending pharyngeal artery; SP: Superior part; MP: Middle part; IP: Inferior part; S: Soft palate; PG: Palatoglossus; SC: Superior constrictor; TVP: Tensor veli palatini; LVP: Levator veli palatini; AT: Auditory tube; T: Tongue; HP: Hard palate.

Table III. Contribution of ascending and lesser palatine arteries to superior part of soft palate. Common Key= P: present; Abs: absent.

\begin{tabular}{|c|c|c|c|c|c|c|c|c|}
\hline & \multicolumn{4}{|c|}{ Ascending Palatine Artery } & \multicolumn{4}{|c|}{ Lesser palatine Artery } \\
\hline & \multicolumn{2}{|c|}{ Fetuses $(n=30)$} & \multicolumn{2}{|c|}{ Adults $(\mathrm{n}=\mathbf{2 0})$} & \multicolumn{2}{|c|}{ Fetuses $(\mathbf{n}=30)$} & \multicolumn{2}{|c|}{ Adults $(\mathrm{n}=20)$} \\
\hline & $\mathbf{P}(\%)$ & $\operatorname{Abs}(\%)$ & $\mathbf{P}(\%)$ & $\operatorname{Abs}(\%)$ & $\mathbf{P}(\%)$ & Abs (\%) & $\mathbf{P}(\%)$ & $\operatorname{Abs}(\%)$ \\
\hline Rigth (n=50) & $7(14)$ & $23(46)$ & $13(26)$ & $7(14)$ & $17(34)$ & $13(26)$ & $8(16)$ & $12(24)$ \\
\hline Left $(n=50)$ & $9(18)$ & $21(42)$ & $8(16)$ & $12(24)$ & $12(24)$ & $18(36)$ & $9(18)$ & $11(22)$ \\
\hline Total $(n=100)$ & $16(16)$ & $44(44)$ & $21(21)$ & $19(19)$ & $29(29)$ & $31(31)$ & $17(17)$ & $23(23)$ \\
\hline
\end{tabular}


Table IV. Contribution of ascending pharyngeal and ascending palatine arteries to middle part of soft palate.

\begin{tabular}{|c|c|c|c|c|c|c|c|c|}
\hline & \multicolumn{4}{|c|}{ Ascending Pharyngeal Artery } & \multicolumn{4}{|c|}{ Ascending Palatine Artery } \\
\hline & \multicolumn{2}{|c|}{ Fetuses $(n=30)$} & \multicolumn{2}{|c|}{ Adults $(\mathrm{n}=20)$} & \multicolumn{2}{|c|}{ Fetuses $(n=30)$} & \multicolumn{2}{|c|}{ Adults $(\mathrm{n}=\mathbf{2 0})$} \\
\hline & $\mathbf{P}(\%)$ & Abs (\%) & $\mathbf{P}(\%)$ & Abs (\%) & $\mathbf{P}(\%)$ & Abs (\%) & $\mathbf{P}(\%)$ & Abs (\%) \\
\hline Rigth $(n=50)$ & $1(2)$ & $29(58)$ & $0(0)$ & $20(40)$ & $22(44)$ & $8(16)$ & $8(16)$ & $12(24)$ \\
\hline Left $(n=50)$ & $1(2)$ & $29(58)$ & $0(0)$ & $20(40)$ & $21(42)$ & $9(18)$ & $10(20)$ & $10(20)$ \\
\hline Total $(n=100)$ & $2(2)$ & $58(58)$ & $0(0)$ & $40(40)$ & $23(43)$ & $17(17)$ & $18(18)$ & $22(22)$ \\
\hline
\end{tabular}
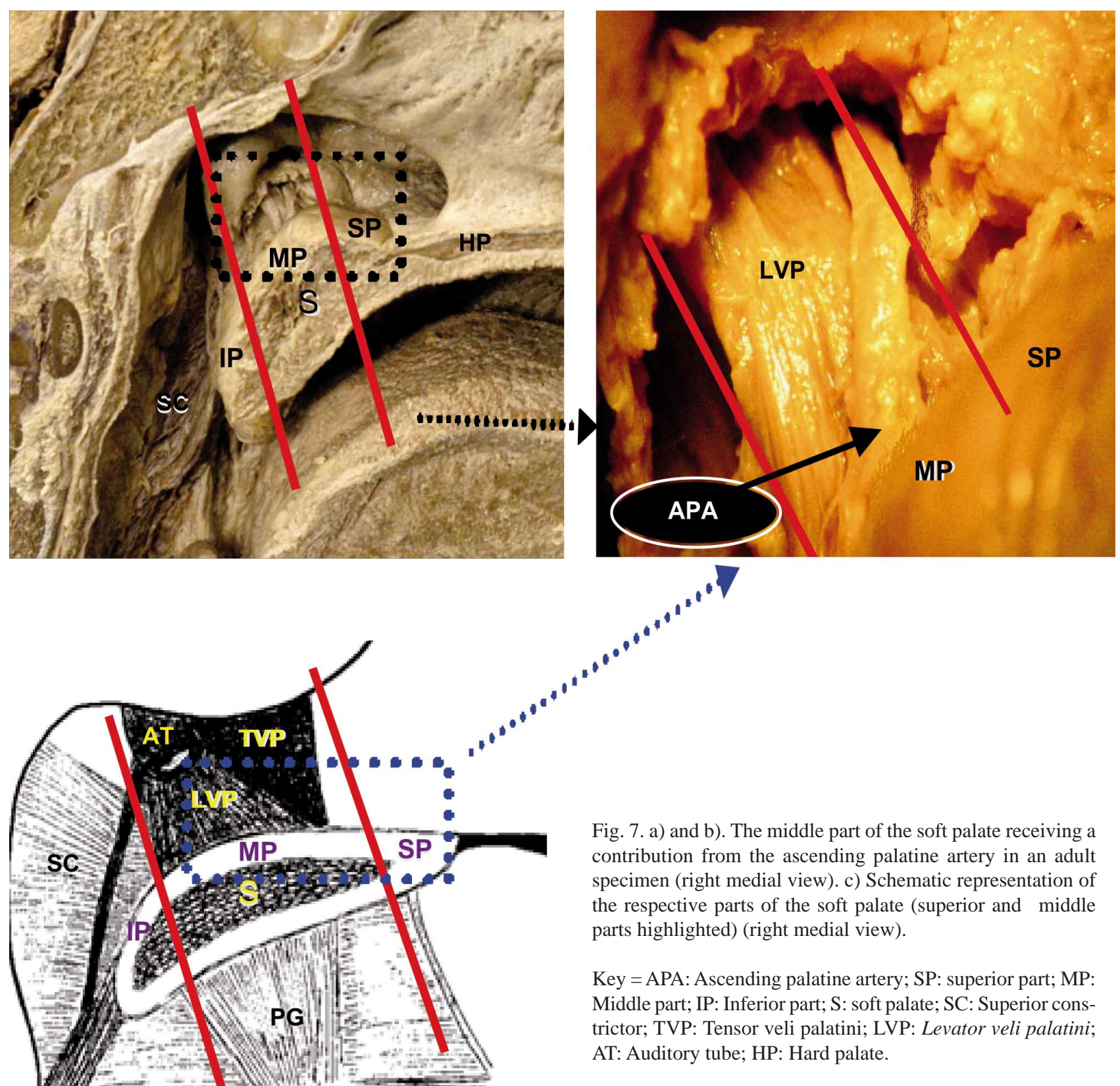


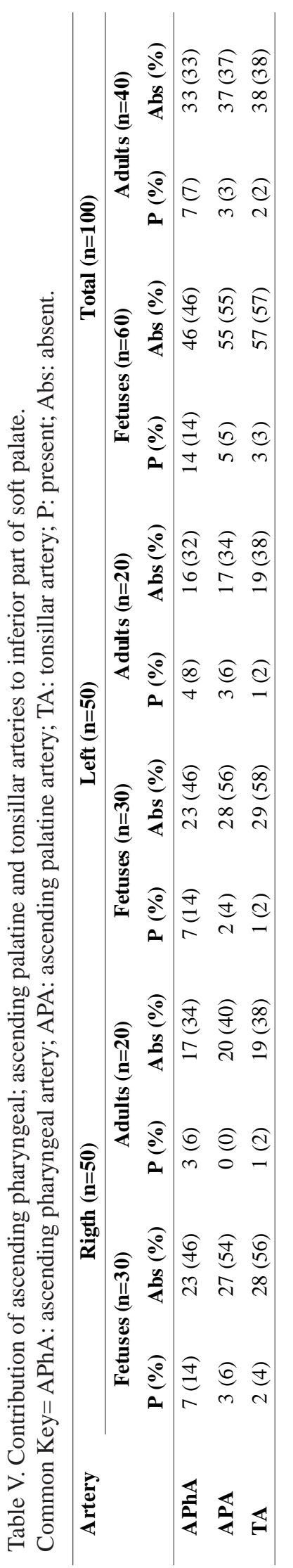

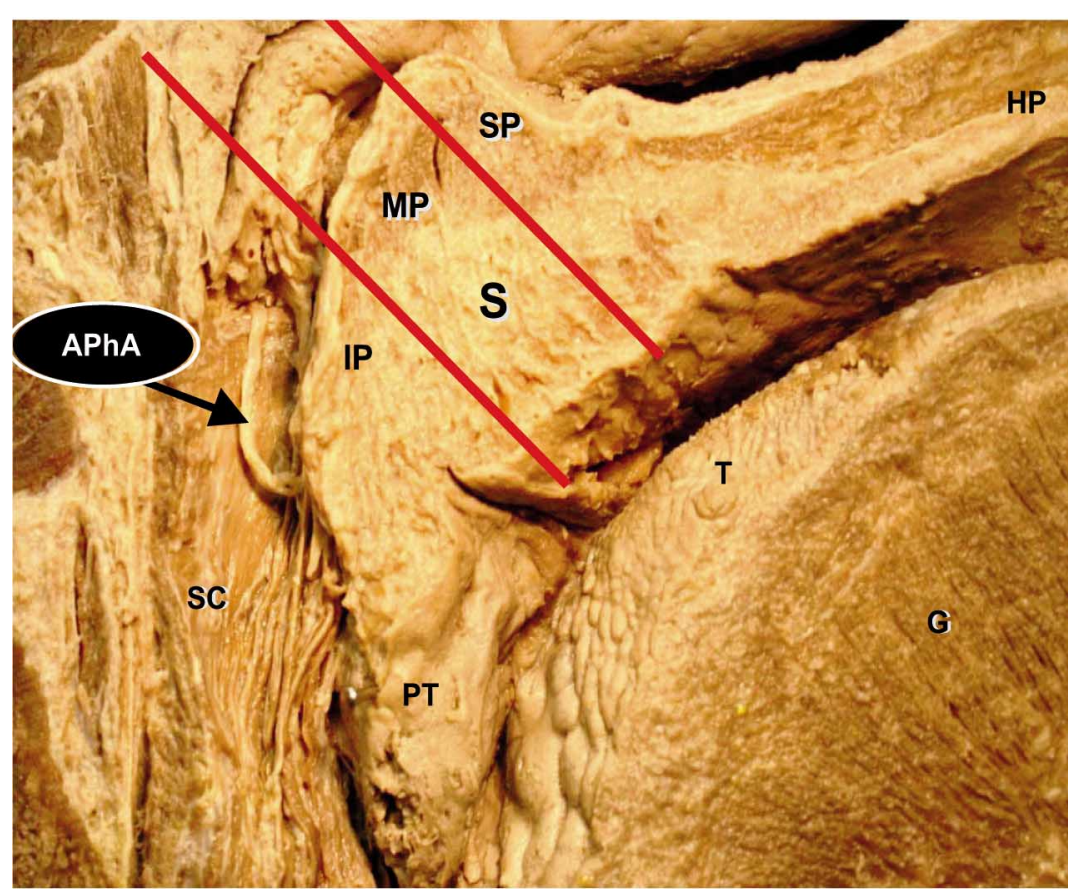

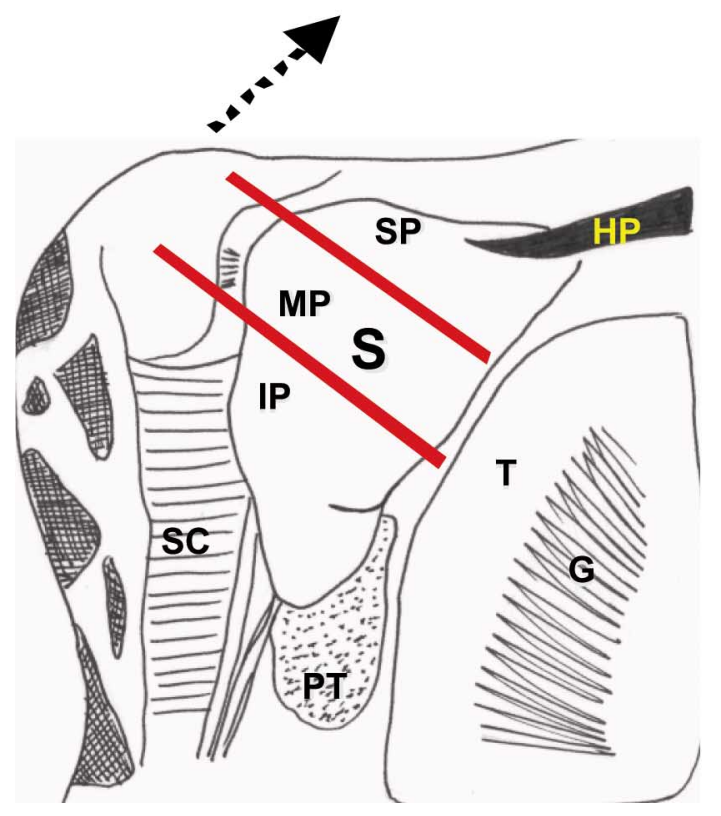

Fig 8. a) The inferior part of the soft palate receiving a contribution from the ascending pharyngeal artery in an adult specimen (left medial view). b) Schematic representation of the respective parts of the soft palate (left medial view).

Key $=$ APhA: Ascending pharyngeal artery; SP: Superior part; MP: Middle part; IP: Inferior part; S: Soft palate; SC: Superior constrictor; PT: Palatine tonsil; T: Tongue; HP: Hard palate; G: Genioglossus. 

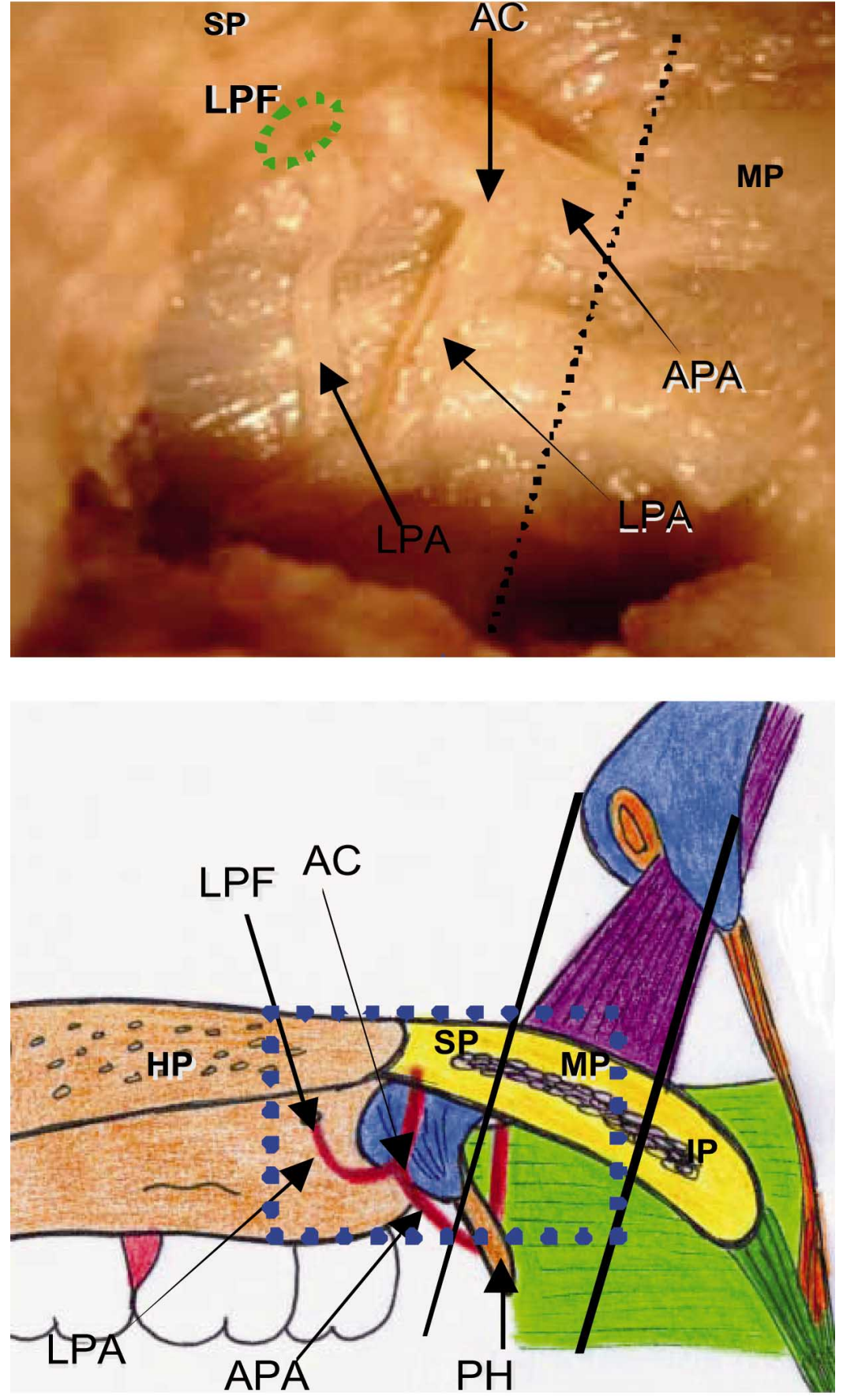

Fig. 9. a). Right medial view of the soft palate demonstrating the anastomotic connection between the ascending palatine and lesser palatine arteries which terminated at the superior part. c). Schematic representation of the respective parts of the soft palate (superior and middle parts highlighted) (right medial view).

Key = AC: Anastomotic connection; LPF: Lesser palatine foramen; LPA: Lesser palatine artery; HP: Hard palate; APA: Ascending palatine artery; PH: Pterygoid hamulus; SP: Superior part; MP: Middle part; IF: Inferior part; HP: Hard palate.

\section{DISCUSSION}

The soft palate has been extensively investigated and reported in the literature; however, its arterial anatomy has been inconsistently described. This investigation therefore aimed to provide a review of the arteries supplying the soft palate. Division of the soft palate into superior, middle and inferior parts by the levator veli palatini and palatoglossus muscles (demonstrated in Table I and Fig. 1) attempted to address the apparent deficiency in the literature regarding the territory of supply for the respective soft palate arteries. Accordingly, this investigation therefore also attempted to provide a detailed and unique description of the arteries terminating at the respective divisions of the soft palate. Moore et al. observed the soft palate receiving a contribution from the greater palatine, ascending palatine and ascending pharyngeal arteries. Unlike Moore's et al. report, the present study exhibited dominant supplies from the ascending palatine and ascending pharyngeal arteries with no contribution from the greater palatine artery. Freelander and Standring reported that the ascending pharyngeal artery provided a significant supply to the soft palate which occasionally replaced the ascending palatine artery when supplying the soft palate. The findings of this investigation demonstrated a single fetal case where the ascending pharyngeal artery replaced the ascending palatine artery, suggesting the predominance of the ascending palatine artery. Salmon (1936) proposed that the ascending palatine artery splits into two branches before supplying the soft palate and Mercer et al. (1995b) confirmed the posterior branch of the ascending palatine artery contributing to the soft palate. The present study observed the division and posterior branches of the ascending palatine artery terminating at the respective parts of the soft palate. Piehslinger et al. (1991) demonstrated multiple arteries supplying the soft palate viz. ascending palatine, ascending pharyngeal and lesser palatine arteries. The findings of this study concurs with Piehslinger et al. and showed the 
ascending palatine, ascending pharyngeal and lesser palatine arteries contributing significantly to the soft palate. Additional contributions to the soft palate from the tonsillar artery (Broomhead; Cheng et al.) and recurrent pharyngeal artery (Huang et al., 1998a, 1998b) were documented. This investigation also demonstrated additional supplies from the tonsillar artery with no contribution from the recurrent pharyngeal artery. Mercer et al. (1995a) demonstrated anastomotic connections between the greater palatine and ascending palatine arteries which terminated at the soft palate whilst Huang et al. (1998a) recorded anastomoses between (i) ascending palatine and recurrent pharyngeal, and (ii) lesser and greater palatine arteries. This study did not observe the latter anastomotic connections. This investigation however, confirmed the findings of Huang et al. (1998a) which demonstrated anastomotic connections between the ascending palatine and lesser palatine arteries. Anastomoses between the lesser palatine, ascending pharyngeal and tonsillar arteries were documented by Cheng et al. The present study did not observe the latter. However, an anastomotic connection between the ascending pharyngeal and recurrent pharyngeal arteries terminating at the soft palate was demonstrated in this investigation. The ascending palatine artery originated from several sources and the most frequent source vessel was the facial artery (63\%) corroborating the description of Mercer et al. (1995a) who demonstrated the latter in $71 \%$ of dissections, whilst the tonsillar artery arose from the facial artery $(100 \%)$, in agreement with Hiatt \& Gartner (2000). The ascending pharyngeal artery originated from the external carotid artery (100\%), concurring with Moore et al. and Standring. This study demonstrated that majority of the arteries terminated at the superior $(83 \%)$ and middle $(63 \%)$ parts, whereas the inferior part (34\%) was documented to receive the poorest arterial supply.

Agur et al. stated that the anterior membranous "aponeurotic palate" of the soft palate (observed in the superior part in this investigation) allows for the origin of the palatoglossus, palatopharyngeus, musculus uvula and the insertion of the levator veli palatini and tensor veli palatini muscles. From this investigation, the superior part demonstrated a rich arterial supply suggesting that vascular disruption in this area is more susceptible and careful dissection is therefore required to prevent wound breakdown. In addition, the aponeurotic palate is supported by the posterior border of hard palate as described by Agur et al. and based on the latter researchers work and the nature of the blood supply it is therefore suggested that dissections performed at the posterior border of hard palate following surgery may increase the risk of breakdown of the soft palate as the area is distant from the arteries and an efficient supply is therefore not provided resulting in critical ischemia. The posterior "muscular palate" (observed in the superior, middle and inferior parts in this investigation) as described by Horeczko et al. (2004) is supported by the palatoglossus, palatopharyngeus, tensor veli palatini, levator veli palatini and the musculus uvula muscles. The findings in this study demonstrate the middle part being supported by the levator veli palatini, tensor veli palatini and palatoglossus muscles, respectively. Due to $63 \%$ of arteries terminating at the middle part, disruption of the ascending pharyngeal and ascending palatine arteries may result in fibrosis of the levator veli palatini, tensor veli palatini and palatoglossus muscles and could possibly be a contributing factor to the breakdown of a cleft palate repair. As stated by Horeczko et $a l$. the posterior "muscular palate" (observed in the superior, middle and inferior parts in this investigation) is supported by the palatoglossus, palatopharyngeus, tensor veli palatini, levator veli palatini and the musculus uvula muscles. This investigation demonstrated the inferior part being supported by the musculus uvula and palatopharyngeus muscles, respectively. It is therefore assumed that the inferior part of the soft palate (which exhibited the poorest arterial supply), would probably have some amount of vascular insufficiency in the event of vascular disruption of the ascending pharyngeal, ascending palatine and tonsillar arteries during the repair of a cleft palate and in the correction of velopharyngeal incompetence, resulting in degeneration of the musculus uvula and the palatopharyngeus muscles. The present investigation observed the anastomotic connections only in $69 \%$ of fetal specimens (believed to be related to the embryological development of the arteries), suggesting that a cleft repair should possibly be performed as soon as possible after birth as the arteries, anastomotic connections and musculature around the cleft is still developing and rupture of the primary artery during palatoplasty could be compensated by the anastomotic connection.

MAISTRY, T.; LAZARUS, L.; PARTAB, P. \& SATYAPAL, K. S. Estudio anatómico de la irrigación arterial del paladar blando. Int. J. Morphol., 30(3):847-857, 2012.

RESUMEN: Este estudio proporciona una descripción detallada de las arterias que irrigan el paladar blando a través de las arterias: (i) palatina ascendente, (ii) tonsilar, (iii) faríngea ascendente, y (iv) palatinas menores. Se realizaron disecciones bilateralmente en 30 cabezas y cuellos de fetos y 20 de adultos ( $\mathrm{n}=$ 100). Esta investigación documentó las arterias que terminaron en diferentes partes (superior, media e inferior) del paladar blando y demostró que la mayoría terminaba a nivel superior (83\%) y medio $(63 \%)$, mientras que la parte inferior $(34 \%)$ recibía un escaso suministro arterial. Se reconocieron conexiones anastomóticas en $6 \%$ de las muestras fetales, (i) entre las aa. palatinas ascendentes y las aa. palatinas menores, que terminaron en la parte superior del paladar blando en $4 \%$ de los casos fetales, y (ii) entre las aa. faríngea ascen- 
dente y faríngea recurrente, que terminaban en la parte inferior en un $2 \%$ de las muestras fetales. La posición y las relaciones de las arterias del paladar blando es relevante para minimizar el riesgo de interrupción vascular y falla de los colgajos miomucosos o mucosos, durante la reparación de paladar hendido o en la corrección quirúrgica de insuficiencia velofaríngea.

PALABRAS CLAVE: Paladar blando; Suministro arterial; Territorio; Anastomosis.

\section{REFERENCES}

Agur, A. M. R. \& Dalley, A. F. Grant's atlas of anatomy. $5^{\text {th }}$ ed. Baltimore, Lippincott Williams \& Wilkins, 2006.

Broomhead, I. W. The nerve supply of the muscles of the soft palate. Br. J. Plast. Surg., 4(1):1-15, 1951.

Cheng, N.; Zhang, K. \& Song, R. Applied anatomy of arterial supply for the soft palate. Zhonghua Kou Qiang Yi Zhi, Za 16(4): 208$11,2000$.

Freedlander, E. Blood supply of the human levator and tensor veli palatini muscles. Clin. Anat., 5(1):34-44, 1992.

Furlow, L. T. Cleft palate repair by double opposing Z-plasty. Plast. Reconstr. Surg., 78(6):724-38, 1986.

Girgis, I. H. Blood supply of the uvula and its surgical importance. J. Laryngol. Otol., 80(4):397-402, 1966.

Hiatt, J. L. \& Gartner, L. P. Textbook of Head and Neck Anatomy. $3^{\text {rd }}$ ed. Philadelphia, Lippincott Williams \& Wilkins, 2000.

Hollinshead, W. H. Anatomy for Surgeons. Head and Neck. Volume 1. New York, Harper and Row, 1954.

Horeczko, T.; Gausche-Hill, M. \& Burbulys, D. Case Presentation \#3: "The Case of the Perilous Pencil". The Pediatric Emergency Medicine Resource, 2004. Available in: http:// www.aplsonline.com/docs/33164_CSDY_pencil.pdf

Huang, M. H.; Lee, S. T. \& Rajendran, K. Clinical implications of the velopharyngeal blood supply: a fresh cadaveric study. Plast. Reconstr. Surg., 102(3): 655-67, 1998.

Huang, M. H.; Lee, S. T. \& Rajendran, K. Anatomic basis of cleft palate and velopharyngeal surgery: implications from a fresh cadaveric study. Plast. Reconstr. Surg., 101(3):613-27, 1998 b.

Hynes, W. Pharyngoplasty by muscle transplantation. Br. J. Plast. Surg., 3(2):128-35, 1950.

Kriens, O. An anatomical approach to veloplasty. Plast. Reconstr. Surg., 43(1):29-41, 1969.
Mercer, N. S. \& MacCarthy, P. The arterial supply of the palate: implications for closure of cleft palates. Plast. Reconstr. Surg., 96(5):1038-44, 1995a.

Mercer, N. S. \& MacCarthy, P. The arterial basis of pharyngeal flaps. Plast. Reconstr. Surg., 96(5):1026-37, 1995 b.

Moore, K. L.; Dalley, A. F. \& Agurquot, A. M. R. Clinically Oriented Anatomy. $6^{\text {th }}$ ed. Philadelphia, Lippincott Williams \& Wilkins, 2009.

Orticochea, M. Construction of a dynamic muscle sphincter in cleft palates. Plast. Reconstr. Surg., 41(4):323-7, 1968.

Piehslinger, E.; Chouéki, A.; Chouéki-Guttenbrunner, K. \& Lembacher, H. Arterial supply of the oral mucosa. Acta Anat. (Basel), 142(4):374-8, 1991.

Rosenthal, W. Zur Frage Der Gaumenplastik. Zentralbl. Chir., $51: 1621,1924$.

Rosselli, S. Divisione palatina e sua aura chirurgica. Alv. Congr. Internax. Stomatol., 36:391, 1935.

Salmon, M. Arteres des Muscles de la Tete et du Cou. Paris, Masson, 1936.

Skoog, T. The pharyngeal flap operation in cleft palate: A clinical study of eighty-two cases. Br. J. Plast. Surg., 18:265-282, 1965

Standring, S. Gray's anatomy. $40^{\text {th }}$ ed. New York, Churchill Livingstone, 2009.

Correspondence to:

Professor KS Satyapal

Department of Clinical Anatomy

School of Laboratory Medicine and Medical Sciences

College of Health Sciences

University of KwaZulu-Natal

Westville Campus

Private Bag X54001

Durban

4001

SOUTH AFRICA

Telephone number: + 27312607195

Fax number: + 27312607890

Email: satyapalk@ukzn.ac.za

Received: 07-03-2012

Accepted: 14-05-2012 